\title{
PROBLEMS IN DATING STONE-AGE SETTLEMENTS ON SANDY SOILS: THE HOF TEN DAMME SITE NEAR MELSELE, BELGIUM
}

\author{
MARK J. Y. VAN STRYDONCK, ${ }^{1}$ JEAN-PIERRE VAN ROEYEN, ${ }^{2}$ GUIDO MINNAERT and \\ CYRIEL VERBRUGGEN ${ }^{3}$
}

\begin{abstract}
Archaeological sites on sandy soils often suffer from dislocation of artifacts and datable materials. Because stratigraphy and context lose their meaning in such cases, all ${ }^{14} \mathrm{C}$ dates in this study were put in a dispersion diagram regardless of the sample origin. We drew conclusions about the chronology of the site by comparing this diagram with archaeological analysis of the artifacts and the evolution of the landscape. The dating series, as well as the archaeological analysis, suggest several occupation phases. In general, the archaeological chronology agrees with the ${ }^{14} \mathrm{C}$ dates, although the two can be equated only with caution.
\end{abstract}

\section{INTRODUCTION}

It is well known that archaeological sites on sandy soils are difficult to date because of the dislocation of the artifacts and datable organic material. We were first confronted with this problem in 1983 when dating the Donk site at Herk-de-Stad, Belgium (Dauchot-Dehon, Heylen and Van Strydonck 1984). Initially, we rejected some dates because they did not agree with the archaeological context. However, when we noticed that the dates agreed with the different occupational phases of the site proposed by archaeologists, we re-evaluated them (Van Strydonck 1992). In our present study, we anticipated the possibility of dislocation and started the dating project assuming that most, if not all, of the samples were no longer in their original context. We sought to avoid a circular argument by initially separating the dating project and the study of the archaeological context. Only after this initial investigation did we compare the two chronological models.

\section{SITE DESCRIPTION}

The site of Hof ten Damme (Fig. 1) at Melsele, O Vlaanderen, Belgium $\left(51^{\circ} 15^{\prime} 01^{\prime \prime} \mathrm{N}, 4^{\circ} 17^{\prime} 40^{\prime \prime} \mathrm{E}\right)$ lies on the east side of a Pleistocene cover sand mound (Fig. 2: B) underlying peaty (Fig. 2: D) and clayey (Fig. 2: E) sediments of the river Schelde. The topography of the site is strongly conditioned by the Tertiary substratum (Fig. 2: A). Against the strongly eroded north side of the mound is a complex deposit of peaty, sandy and clayey sediments (Fig. 2: C). The top of the deposits is weathered, and we noticed a hiatus in the sedimentation, indicating that this surface was exposed for a considerable time. This complex as well as the higher-positioned cover sands is covered with a peat layer (Fig. 2: D) and alluvial sediments (Fig. 2: E). Archaeological material (van Berg, Van Roeyen and Keeley 1991) from the Late Mesolithic and Neolithic was found in the homogenized topsoil of the mound. Bioturbation had caused vertical displacement of the artifacts and datable materials, except for the bark lining of a probable storage pit. Artifacts and charcoal were also found in large bowlshaped pits, probably windblows. Some material was redeposited by erosion in the sediments against the north flank of the mound. Little material was found at the base of the peat layer or of the mound. The artifacts include lithic objects (14,000 fragments), ceramics (1500 fragments), bone fragments (from wild and domesticated animals), charcoal and hazelnuts.

\footnotetext{
${ }^{1}$ Royal Institute for Cultural Heritage, Jubelpark 1, B-1040 Brussels, Belgium

${ }^{2}$ Archeologische Dienst Waasland, Regentiestraat 63, B-9100 Sint-Niklaas, Belgium

${ }^{3}$ Geological Institute, University of Gent, Krijgslaan 281, S8/A1, B-9000 Gent, Belgium
} 


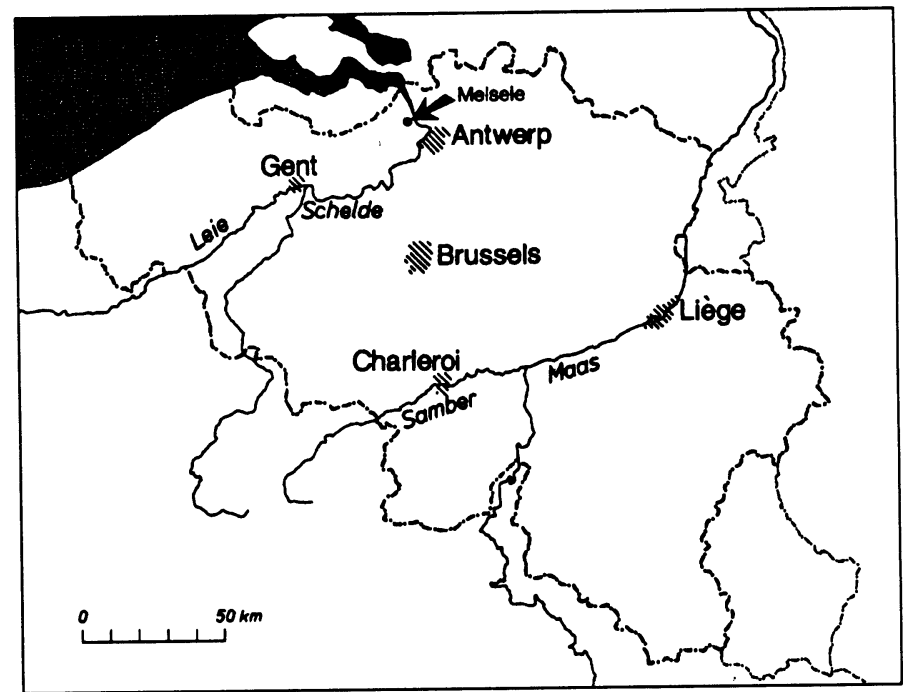

Fig. 1. Map of site location near Melsele

\section{Results}

\section{Geological Samples}

Table 1 lists the dates from three profiles. The top and base of the peat layers and sublayers were dated, as well as some organic deposits. However, the dates of these organic deposits may have been affected by contamination and oxidation, resulting in migration of organic matter. One younger sample (IRPA-958) comes from a gully and is probably taken from a renewed peat growth.

TABLE 1. Geological Samples

\begin{tabular}{|c|c|c|c|c|c|}
\hline Sample* & Lab no. & Sample location & T.A.W.† (cm) & Age BP & $\delta^{13} C(\% 0)$ \\
\hline a & IRPA-958 & $\begin{array}{l}\text { Profile I } \\
\text { Peat from gully } \\
\text { Profile II }\end{array}$ & $221-223$ & $1450 \pm 80$ & -27.8 \\
\hline $\begin{array}{l}\text { b } \\
\text { c } \\
\text { d } \\
\text { e } \\
\text { f } \\
\text { g } \\
\text { h }\end{array}$ & $\begin{array}{l}\text { IRPA-957 } \\
\text { IRPA-956 } \\
\text { IRPA-955 } \\
\text { IRPA-954 } \\
\text { IRPA-953 } \\
\text { IRPA-952 } \\
\text { IRPA-951 }\end{array}$ & $\begin{array}{l}\text { End peat formation } \\
\text { Peat sublayer } \\
\text { Peat sublayer } \\
\text { Peat sublayer } \\
\text { Peat sublayer } \\
\text { Peat sublayer } \\
\text { Basal peat formation }\end{array}$ & $\begin{array}{l}228-230 \\
212-214 \\
206-208 \\
194-196 \\
186-188 \\
175-177 \\
165-166\end{array}$ & $\begin{array}{l}1770 \pm 40 \\
2310 \pm 40 \\
2800 \pm 45 \\
3300 \pm 40 \\
3500 \pm 45 \\
3540 \pm 50 \\
4080 \pm 60\end{array}$ & $\begin{array}{l}-29.0 \\
-28.4 \\
-28.7 \\
-28.9 \\
-28.2 \\
-27.2 \\
-27.5\end{array}$ \\
\hline $\begin{array}{l}\mathrm{i} \\
\mathrm{j} \\
\mathrm{k} \\
\mathrm{l} \\
\mathrm{m} \\
\mathrm{n} \\
\mathrm{o}\end{array}$ & $\begin{array}{l}\text { IRPA-950 } \\
\text { IRPA-949 } \\
\text { IRPA-947 } \\
\text { IRPA-946 } \\
\text { IRPA-944 } \\
\text { IRPA-943 } \\
\text { IRPA-942 }\end{array}$ & $\begin{array}{l}\text { Profile III } \\
\text { Top peat layer } \\
\text { Sublayer } \\
\text { Basal peat layer } \\
\text { Top peat layer } \\
\text { Basal peat layer } \\
\text { Organic layer } \\
\text { Organic layer }\end{array}$ & $\begin{array}{c}182-184 \\
108-112 \\
50-52 \\
20-24 \\
-15 \text { to }-19 \\
-21 \text { to }-26 \\
-48 \text { to }-56\end{array}$ & $\begin{array}{l}1915 \pm 40 \\
2900 \pm 50 \\
4300 \pm 60 \\
5000 \pm 40 \\
5350 \pm 50 \\
5160 \pm 60 \\
5300 \pm 70\end{array}$ & $\begin{array}{l}-28.5 \\
-28.3 \\
-28.5 \\
-25 \S \\
-27.0 \\
-27.2 \\
-27 \S \\
\end{array}$ \\
\hline
\end{tabular}

*See Fig. 2

$\dagger$ T.A.W.: Tweede Algemene Waterpassing = Belgian ordnance datum ‡IRPA = Royal Institute for Cultural Heritage, Brussels 


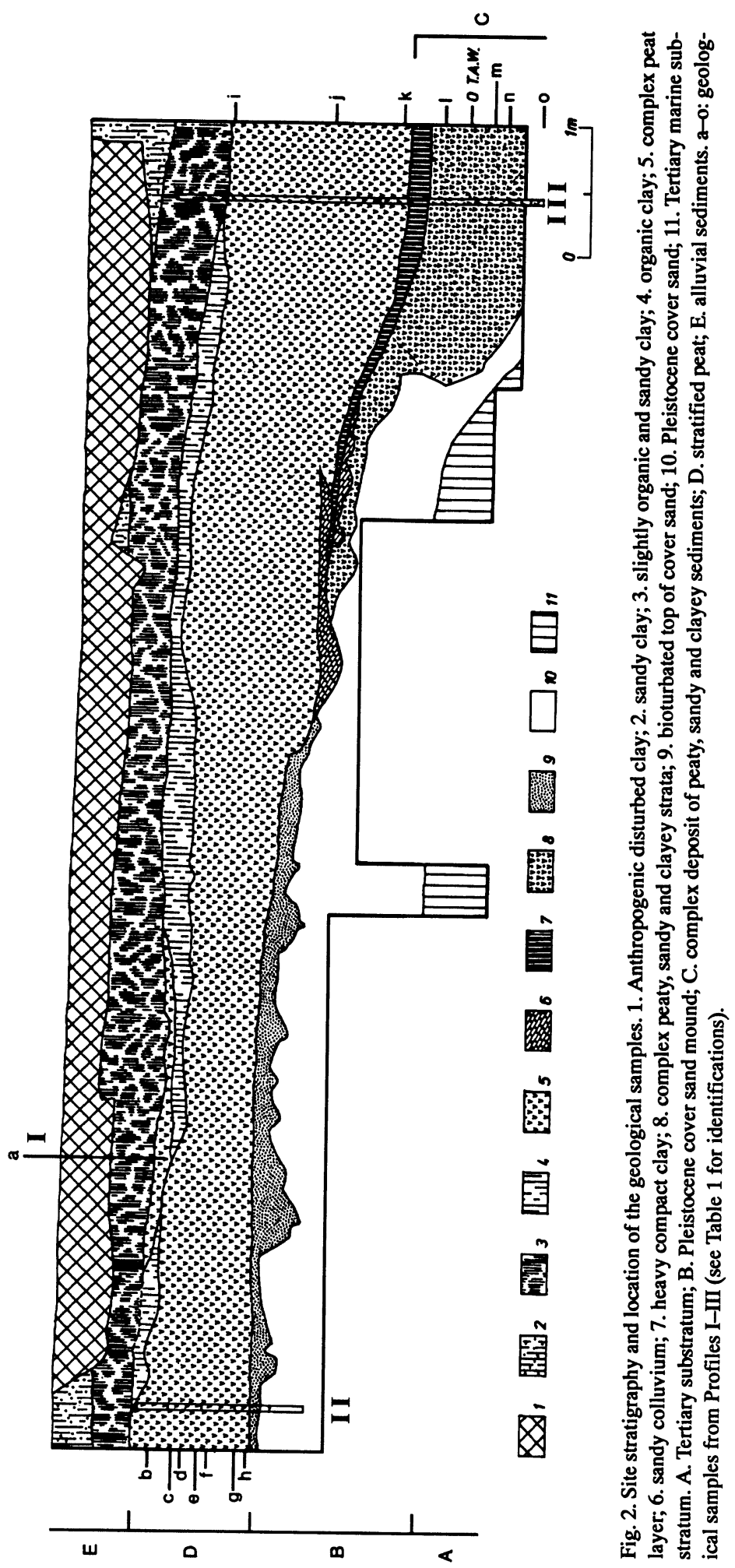




\section{Archaeological Samples}

Table 2 lists the dates of 15 archaeological samples. Figure 3 shows the dispersion diagram (Ottaway 1973) of the conventional (A) and the calibrated (B) dates. The diagram of the conventional dates is the sum of the Gaussian distributions of each single date. The calibrated diagram is obtained by the sum-probabilities option in the Stuiver and Reimer (1993) calibration program. The diagrams show single results at $c a .9000,7700$ and $3200 \mathrm{BP}$. Two almost identical dates, but on different material, are at $5700 \mathrm{BP}$. Ten dates form a cluster, incorporating almost the entire 5th millennium BP. The two dates obtained on the bark from the pit mark the beginning of this cluster (average of the two $=$ $5040 \pm 60 \mathrm{BP}$ ). The youngest sample (IRPA-938) dates to $c a .3200 \mathrm{BP}$ and was found in the same context (windblow $\alpha$ ) as the oldest sample (IRPA-933). UtC-1351 and IRPA-937 were also found in the same context (windblow $\beta$ ). IRPA-1040 is part of the cluster although the sample comes from a stratigraphically much younger context. We noted evidence of migration not only of small or single lumps of charcoal, but conglomerates $(>10 \mathrm{~g})$ were also displaced.

TABLE 2. Archaeological Samples

\begin{tabular}{lllrrl}
\hline No. & Lab no. & Material dated & T.A.W. $(\mathrm{cm})$ & Age BP & $\delta^{13} \mathrm{C}(\%)$ \\
\hline 1 & IRPA-938 & Charcoal from windblow $\alpha$ & $100-105$ & $3210 \pm 60$ & -25.2 \\
2 & UtC-1445* & Wood from gully & $95-100$ & $4180 \pm 50$ & -27.4 \\
3 & IRPA-1040 & Charcoal from peat base & $130-135$ & $4370 \pm 65$ & -26.0 \\
4 & IRPA-988 & Charcoal from transition peat/ & $150-155$ & $4460 \pm 35$ & -26.5 \\
& & cover sand & & & \\
5 & UtC-1430 & Charcoal from gully & $95-100$ & $4520 \pm 100$ & -25.9 \\
6 & IRPA-934 & Charcoal from cover sand & $150-155$ & $4610 \pm 60$ & -25.4 \\
7 & UtC-1444 & Charcoal from cover sand & $135-140$ & $4660 \pm 60$ & -25.1 \\
8 & IRPA-937 & Charcoal from windblow $B$ & $120-130$ & $4850 \pm 50$ & -26.2 \\
9 & OxA-3092* & Bark from storage pit & -- & $4950 \pm 80$ & -26.0 \\
10 & UtC-1352 & Charcoal from cover sand & $135-140$ & $5090 \pm 80$ & -24.4 \\
11 & OxA-3087 & Bark from storage pit & -- & $5130 \pm 80$ & -26.0 \\
12 & IRPA-945 & Wet wood from cover sand & $135-140$ & $5690 \pm 55$ & -25.3 \\
13 & UtC-3191 & Carbonized hazel nut from cover & $150-155$ & $5700 \pm 60$ & -27.2 \\
& & sand & & \\
14 & UtC-1351 & Charcoal from windblow $B$ & $130-135$ & $7730 \pm 110$ & -24.6 \\
15 & IRPA-933 & Charcoal from windblow $\alpha$ & $125-130$ & $9030 \pm 70$ & -27.3 \\
\hline
\end{tabular}

*UtC = samples prepared in Brussels and measured at the Van der Graaff Laboratory, University of Utrecht; OxA = Oxford Radiocarbon Accelerator Unit

\section{Discussion}

\section{$>5690$ BP}

In spite of the mixing of the artifacts, at least two distinct phases could be recognized based on the typology of the lithic material. Most of the lithics belong to the Late Mesolithic tradition, which thus postdate $8 \mathrm{ka}$ BP. Only a few tools can clearly be attributed to the Neolithic. The pottery shows distinct technical groups and does not seem to belong to one of the known Early or Middle Neolithic groups. A more-or-less similar situation occurs at the site of Weelde-Paardsdrank (Huyge and Vermeersch 1982). One ${ }^{14} \mathrm{C}$ date at Hof ten Damme (UtC-1351: $7730 \pm 110 \mathrm{BP}$ ) corresponds with the Late Mesolithic. Two dates (UtC-3191: $5700 \pm 60$ BP, IRPA-945: $5690 \pm 55 \mathrm{BP}$ ) might correspond with a Late Mesolithic survival of "ceramized" hunters (Van Roeyen and van Berg 1989). The site 
of Weelde-Paardsdrank yielded a similar date (Lv-934: $5710 \pm 80 \mathrm{BP}$ ), whose close agreement with our dates is unlikely to be coincidental.

Lithic typology is inconclusive concerning possible human occupation of the site ca. $9 \mathrm{ka} \mathrm{BP}$. However, two similar sites at the neighboring village of Verrebroek (Van Hove and Van Roeyen 1988; Crombé 1994) yield three nutshell dates of the same period (UtC-2743: $9000 \pm 190 \mathrm{BP}$; UtC-2744: $8920 \pm 130 \mathrm{BP}$; IRPA-633: $8890 \pm 100 \mathrm{BP}$ ). The anthropogenic origin of the charred nutshell is beyond doubt. Sporadic use of the Hof ten Damme site dated by a charcoal deposit (IRPA-933: 9030 $\pm 70 \mathrm{BP}$ ) can be neither ruled out nor fully proven.
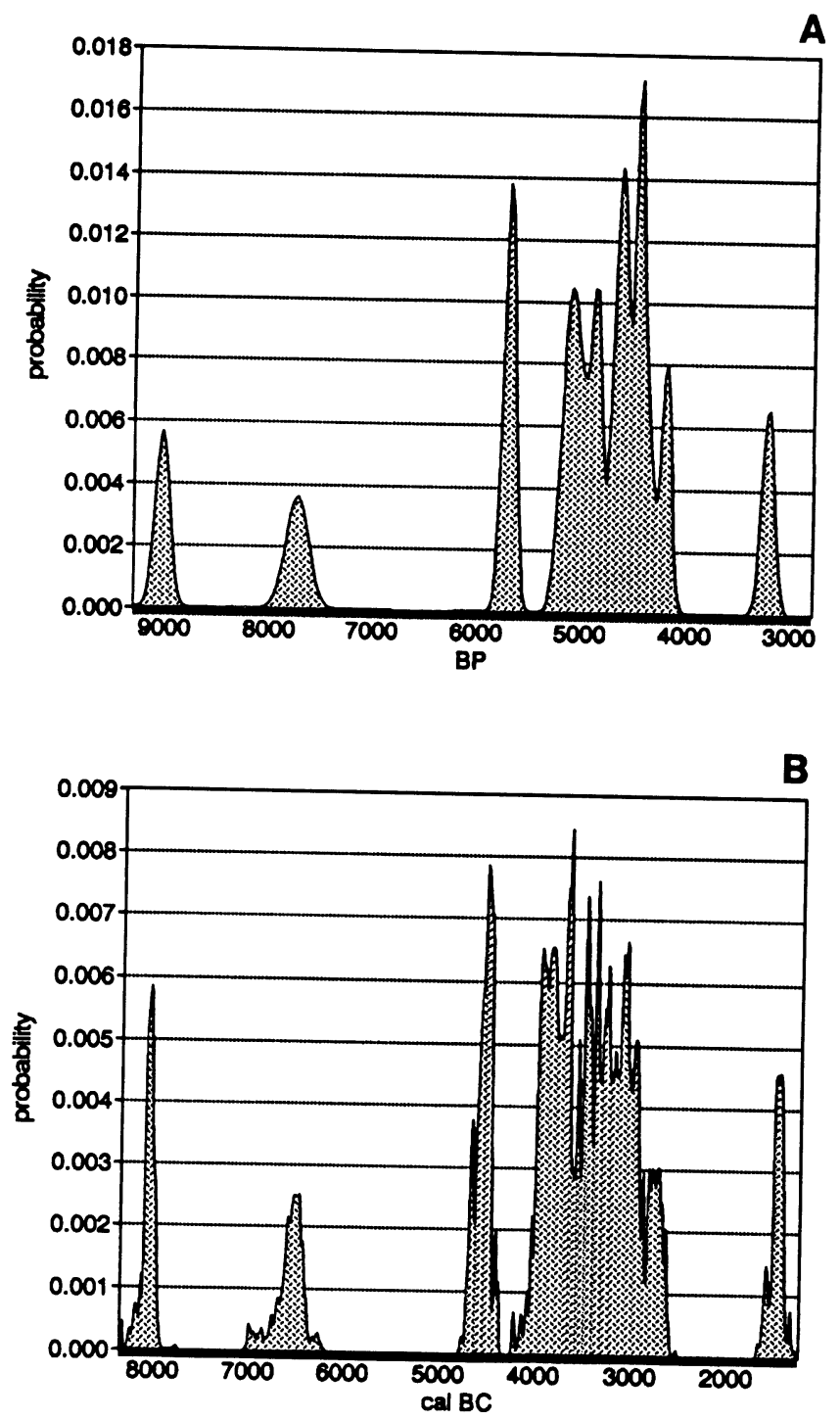

Fig. 3. Dispersion diagram of 15 archaeological samples. A. Conventional dates; B. Calibrated dates. 


\section{0-5000 BP}

Diatom and pollen analyses (Denys and Verbruggen 1989) of the sediments at the north flank of the mound (Fig. 2: C) revealed a deposition in a brackish environment, demonstrating an important downstream supply of sediments by tidal activity. This sedimentation begins ca. 5300 BP (IRPA942) and ends $c a .5000 \mathrm{BP}$ (IRPA-946). A similar deposit from the same period is also dated in a peat sequence at the nearby village of Doel (Minnaert and Verbruggen 1986) (base, IRPA-457: $5350 \pm 70$ $\mathrm{BP}$; top, IRPA-454: $4900 \pm 60 \mathrm{BP}$ ). During this active sedimentation period no clear evidence of human activity on the site could be found in the pollen analyses. The top of this complex is a weathered compact clay and was probably a surface for more than a century.

\section{$5000-4300$ BP}

After $5 \mathrm{ka} \mathrm{BP}$, tidal activity disappeared. The age of one charcoal sample (UtC-1352) and the average of the bark dates (OxA-3092 and -3087) correspond with the end of this active sedimentation and the beginning of a period of stagnation in the Holocene floodplain expansion of the river Schelde. A cluster containing $10^{14} \mathrm{C}$ dates covers a period of $c a .800{ }^{14} \mathrm{C} \mathrm{yr}(5000-4200 \mathrm{BP})$. It is important to emphasize that the bark lining of the pit was the only sample that was undoubtedly still in situ. The few Neolithic stone tools, some ceramics and probably most of the bones from domesticated fauna can be related to this phase. Although the dates reveal human activity for almost $800{ }^{14} \mathrm{C}$ yr, within the excavated area, no evidence was found for permanent occupation.

\section{$<4300$ BP}

At the lower portion of the mound (50-52 cm T.A.W.), peat (Fig. 2: D) started growing ca. $4300 \mathrm{BP}$ (IRPA-947). At the higher parts (165-166 cm), the peat growth started at ca. $4000 \mathrm{BP}$ (IRPA-951). These dates correspond to the youngest dates of the cluster, namely the sample from the peat base (130-135 cm T.A.W.) (IRPA-1040: $4370 \pm 65 \mathrm{BP}$ ) and the one (95-100 cm T.A.W.) (UtC-1445: 4180 $\pm 50 \mathrm{BP}$ ) found in a younger deposit. From that time on, the landscape is characterized by a peat bog dominated by alder. The top of this peat layer is covered by a clastic alluvium (Fig. 2: E), according to pollen analysis, caused by the Dunkerk-II transgression, as confirmed by a ${ }^{14} \mathrm{C}$ date of $1770 \pm 60$ BP (IRPA-957). No trace of human activity could be demonstrated either archaeologically or palynologically between $4 \mathrm{ka}$ BP and the Middle Ages. This implies that the youngest charcoal date (IRPA938: $3210 \pm 60 \mathrm{BP})$ cannot be anthropogenic. The Medieval moated site Hof ten Damme was dated to 1000-1200 cal AD (Van Hove 1988).

\section{CONCLUSION}

Dislocated samples can give chronological information about the archaeological phases of a site. The classical relations between dates, stratigraphy and artifacts must be abandoned, however. We initially put all dates from the site in a dispersion diagram, regardless of their origin. Then the dates were related to: 1) the artifacts; 2) similar dates from related sites; and 3) information obtained from pollen analysis and environmental studies. This made it possible to identify the cluster of dates in the 5 th millennium BP and to conclude that this occupation phase was determined by the tidal activity of the river Schelde. This cluster would not have been noticed if the dates had been ranked according to stratigraphic position or artifactual assemblage. The ${ }^{14} \mathrm{C}$ dates also indicate an occupation $c a$. $5700 \mathrm{BP}$. The relation between this phase and a Late Mesolithic survival remains to be established. The oldest charcoal date may be anthropogenic, but the youngest probably is not. Our inability to distinguish anthropogenic from natural charcoal is a major limitation of this method. It must also be emphasized that random sampling is essential, since there are no longer any real selection criteria. 


\section{ACKNOWLedgments}

The authors wish to thank R. Van Hove, head of service of the Archeologische Dienst Waasland, for his kind permission to use the data from the 1984-1986 excavations conducted under his direction. L. Keeley, University of Illinois, Chicago, directed the 1990 campaign at Melsele and informed us of the Oxford dates. The illustrations for this article were drawn by N. Tasseel, Archeologische Dienst Waasland.

\section{REFERENCES}

Crombé, P. 1994 Recherche poursuivie sur le mésolithique en Flandre Orientale. Notae Praehistoricae 13: 71-78.

Dauchot-Dehon, M., Heylen, J. and Van Strydonck, M. 1984 Institut Royal du Patrimoine Artistique radiocarbon dates X. Radiocarbon 26(3): 384-391.

Denys, L. and Verbruggen C. 1989 A case of drowningthe end of Subatlantic peat growth and related palaeoenvironmental changes in the lower Scheldt basin (Belgium) based on diatom and pollen analysis. $R e$ view of Palaeobotany and Palynology 59:7-36.

Huyge, D. and Vermeersch, P.M. 1982 Late Mesolithic settlement at Weelde-Paardsdrank. In Vermeersch, P. M. ed., Contributions to the study of the Mesolithic of the Belgian Lowland. Studia Praehistorica Belgica 1: 115-209.

Minnaert, G. and Verbruggen C. 1986 Palynologisch onderzoek van een veenprofiel uit het Doeldok te Doel. Bijdragen van de Archeologische Dienst Waasland 1: 201-208.

Ottaway, B. 1973 Dispersion diagrams: A new approach to the display of ${ }^{14} \mathrm{C}$ dates. Archaeometry $15(1): 5-12$.

Stuiver, M. and Reimer, P. 1993 Extended ${ }^{14} \mathrm{C}$ data base and revised CALIB $3.0{ }^{14} \mathrm{C}$ age calibration program. In Stuiver, M., Long, A. and Kra, R. S., eds., Calibration 1993. Radiocarbon 35(1): 215-230.

van Berg, P. L., Van Roeyen, J. P. and Keeley, L. H. 1991 Le site mésolithique acéramique de Melsele (Flandre Orientale), campagne de 1990. Notae Praehistoricae 10: $37-47$.

Van Hove, R. 1988 Melsele (Beveren, O.-Vl.): Hof ten Damme. Archeologie 2: 174-175.

Van Hove, R. and Van Roeyen, J. P. 1988 Verrebroek (Beveren, O.-Vl.): Vroeg-mesolitisch site. Archeologie 2: 150-151.

Van Roeyen, J. P., van Berg, P. L. 1989 Les Chasseurs "ceramisés" du pays de Waas. Notae Praehistoricae 9: 31-32.

Van Strydonck, M. 1992 Radiokoolstof: Een Maat voor het Verleden. Koninklijk Instituut voor het Kunstpatrimonium, Brussels: 80 p. 